\title{
THE EFFICACY OF A READING ALOUD TASK IN THE TEACHING OF PRONUNCIATION
}

\author{
María Martínez Adrián \\ University of the Basque Country
}

\begin{abstract}
Empirical studies have shown that explicit instruction leads to the improvement of perception (e.g. Strange and Dittman 1984; Jamieson and Morosan 1986; Cenoz and García Lecumberri 1999) and oral production (e.g. Couper 2003; Derwing and Munro 2005; Smith and Beckman 2005). Nonetheless, it is necessary to test different types of activities intended for the explicit teaching of pronunciation. This action-research study aims to test the efficacy of a reading aloud task with a noticing and an awareness component in the teaching of pronunciation, and to gauge learners' beliefs regarding the use of this learning tool.

Twenty first-year students of the BA in English Studies at the University of the Basque Country participated in the investigation. Ten written texts were selected by the instructors in order to practice reading aloud for ten weeks. Students went through two phases when doing this task in class: noticing and awareness. They were tested on articulation of sounds, stress placement and intonation through two different texts at two different times. Students were also administered a questionnaire to analyze their opinions regarding the usefulness of this learning task. The assessment of the recordings revealed that learners obtained better means in the case of the second text analyzed. Similarly, the analysis of the responses given to the questionnaire indicated that students considered the reading aloud task a good instrument to improve their pronunciation in English.
\end{abstract}

Keywords: Pronunciation, explicit instruction, reading aloud practice, noticing and awareness. 


\title{
LA EFICACIA DE UNA TAREA DE LECTURA EN VOZ ALTA EN LA ENSEÑANZA DE LA PRONUNCIACIÓN
}

\begin{abstract}
RESUMEN. Estudios empíricos han demostrado que la enseñanza explíita de la pronunciación redunda en una mejoría tanto a nivel de percepción (Strange y Dittman 1984; Jamieson y Morosan 1986; Cenoz y Garcia Lecumberri 1999, entre otros) como de producción oral (Couper 2003; Derwing y Munro 2005; Smith y Beckman 2005, entre otros). Sin embargo, se hace necesario testar diferentes actividades dirigidas a la enseñanza explicita de la pronunciación. El objetivo de esta investigación-acción es testar la eficacia del uso de una tarea de lectura en voz alta con un componente de percepción y conciencia en la enseñanza de la pronunciación y por otro lado, recabar las opiniones de los estudiantes acerca del uso de esta herramienta.

Veinte estudiantes de primer curso de Estudios Ingleses de la Universidad del País Vasco participaron en este estudio. Diez textos escritos fueron seleccionados por los profesores para practicar la lectura en voz alta durante 10 semanas. Los estudiantes atravesaron dos fases en cada texto de lectura en voz alta: percepción y conciencia. Fueron testados a nivel de articulación de sonidos, acentuación y entonación por medio de dos textos distintos en dos momentos diferentes en el tiempo. Se administró también un cuestionario para analizar sus opiniones sobre la eficacia de esta tarea de lectura en voz alta en su aprendizaje de la pronunciación. La evaluación de las grabaciones reveló mejores puntuaciones en el segundo texto analizado y por tanto una mejoría en todas las categorías analizadas. Del mismo modo, el análisis del cuestionario también indicó que los estudiantes consideraban esta herramienta de gran utilidad para la mejoría de su pronunciación en inglés.
\end{abstract}

Palabras clave: Pronunciación, enseñanza explícita, práctica de lectura en vOz alta, percepción y conciencia.

\section{INTRODUCTION}

It is undeniable that pronunciation is one of the most important aspects of oral communication. As Jenkins (2000) states, intelligible pronunciation is a sine quanon condition for oral communication. Despite its importance, English as a Foreign language (EFL) courses often treat it as a subpart of speaking and listening and it is usually taught in an implicit way, which does not seem to lead to much improvement. However, empirical research has attested the effectiveness of explicit instructional techniques in the teaching of pronunciation. For example, noticing activities such as the comparison of learners' reading aloud to a model provided by a teacher enables the learner to notice the difference between both productions and 
in turn to improve their pronunciation (e.g., Couper 2003; Smith and Beckmann 2005). But other teaching techniques such as noticing followed by an awareness phase should be investigated as well. By means of awareness activities, learners engage in some degree of metalinguistic reflection. For example, by means of the analysis of a transcription in terms of different features as regards syllabic consonants, the use of weak forms, among others, learners' attention can be drawn to problematic aspects of the reading aloud. This paper aims at testing the efficacy of a reading aloud task with a noticing and awareness component in a spoken English course addressed to university students. It will also explore learners' opinions regarding the use of this learning task in pronunciation.

This paper is organized as follows. The first two sections tackle the teaching of pronunciation and the role of explicit instruction in second (L2) language learning. The next section presents the methodology of the study. Then the results obtained by the learners are shown and discussed. The paper finishes with the main conclusions drawn from the study.

\section{THE TEACHING OF PRONUNCIATION}

Pronunciation is one of the most important areas in the acquisition of a L2. In fact, for Setter and Jenkins (2005) this linguistic component is the most important factor so as to achieve a successful oral communication and it plays a relevant role in the personal and social life of any human being. Despite its importance and the increasing attention that has received on the part of foreign language (FL) teachers since the 1990s, it is still a marginal area in Applied Linguistics (Jones 1997; Barrera Pardo 2004; Derwing and Munro 2005; Setter and Jenkins 2005; Gallardo del Puerto and Gómez Lacabex 2008). In the Spanish school context, many teachers do not pay attention to pronunciation, and even in those language courses in which pronunciation is tackled, it is usually treated implicitly. In fact, first year university students of English Studies usually argue that they have never been taught pronunciation in an explicit way, as they have never received instruction regarding the characteristics of sounds of the target language (TL) with respect to place, manner and voice or regarding differences between the first language (L1) and the TL sound systems. Some of them even claim that they were not corrected when they produced a wrong sound during their school years. This is very often explained by teachers' feeling of obligation to comply with the curriculum or simply because of the lack of training in pronunciation (Gallardo del Puerto 2005).

Without special training, teachers tend to rely on their own intuitions but this is unrealistic and unfair (Derwing and Munro 2005). Teacher training can contribute to higher levels of phonetic awareness in foreign language teachers (Goldsworthy 1998; 
García Lecumberri 2001) which in turn will enable the teacher to tackle phonetic correction in the classroom more comfortably and will facilitate learners' phonetic awareness, which as has been shown, would eventually lead to pronunciation improvement (Benson and García Mayo 2008). Nonetheless, we cannot forget that there is scarce attention to pronunciation teaching in authoritative texts as well as very little reliance on the research that exists. All in all, instructors should have opportunities to learn about pronunciation pedagogy which should be grounded in research findings (Derwing and Munro 2005). In addition, a greater collaboration between researchers and practitioners to encourage more classroom relevant research should exist.

\section{EXPLICIT INSTRUCTION}

Pennington (1997) argues that most part of the improvement in the learning of a L2 stems from consciousness and awareness on the part of the learner (Schmidt 1990). It is true that teachers are to provide the contexts for perception and production of new sounds (Kenworthy 1989). However, this may not be sufficient. Learners need not only imitation of sounds but also articulatory hints (place and manner of articulation, voice and lip position) (Gallardo del Puerto and Gómez Lacabex 2008). They are also in need of feedback in order to prevent "fossilized phonological performance that can have a negative effect on communication" (Pennington 1997: 82-83).

This goes in line with Sharwood Smith's (1981) arguments that consciousness and awareness raising are important in SLA as well as with a explicit teaching of form in the classroom (Spada 1997), rather than with Krashen's (1982) position that pronunciation is acquired naturally provided that input is understood and there is enough of it. Several studies suggest that form-focused instruction in the form of noticing and language awareness activities together with corrective feedback provided within the context of communicative and content-based programmes tend to be more effective in promoting second language learning than programmes that are limited to an exclusive emphasis on comprehension, fluency, or accuracy alone (Lyster 2007; Lightbown and Spada 2013). According to Lyster (2007) two phases are required for learners to notice target features in a manner robust enough to make the forms available as intake: a noticing phase and an awareness phase. In the noticing phase, learners' attention is drawn to problematic target features by for example 'input enhancement' (Sharwood Smith 1993) which includes typological enhancement such as colour coding or boldfacing in the case of written input, and intonational stress and gestures in the case of oral input. In the awareness phase, learners do more than merely notice 
enhanced forms in the input. They engage in some degree of elaboration (Sharwood Smith 1981, 1993) which may encompass inductive rule-discovery tasks and opportunities to compare and contrast language patterns in the L1 and the L2, followed by different types of metalinguistic information.

Empirical research has shown that explicit instruction helps the learner in noticing the difference between their own productions and those of L1 speakers with respect to certain grammar points (Spada 1997). Similarly, students learning L2 pronunciation benefit from explicit instruction of phonological form, which helps them notice the differences between their own pronunciation and that of proficient speakers in the L2 community (Derwing and Munro 2005). Even though studies that assess the teaching of pronunciation are still scarce, they have been able to show that explicit instruction results in the improvement of oral perception (Strange and Dittman 1984; Jamieson and Morosan 1986; Cenoz and García Lecumberri 1999; Gómez Lacabex and Gallardo del Puerto 2014) and oral production (de Bot 1983; Leather 1990; Couper 2003; Derwing and Munro 2005; Smith and Beckman 2005, among others). But despite pre-post test experimental research attesting the effectiveness of explicit instructional techniques, there is scarcity of exercises addressed at working out phonological skills (Martínez Adrián, Gallardo del Puerto and Gutiérrez Mangado 2013). Instructional materials and practice are still heavily influenced by commonsense intuitive notions, and therefore, the need for empirical, replicable studies to inform pronunciation instruction is clear (Derwing and Munro 2005). Hence, it seems necessary to test different types of activities aimed at the explicit teaching of pronunciation. Although action-research is not very common among teachers, it has been found to have a profound effect on those who have done it (Atay 2007). It has also been attested that action-research produces knowledge about teaching and learning useful to other teachers, policy makers, academic researchers and teacher educators (Francis, Hirsh and Rowland 1994). Thus, action-research is clearly advocated in the case of the teaching of pronunciation, as it allows the teacher to test the efficacy of activities aimed at the explicit teaching of pronunciation.

Several action research studies have attested the value of a reading aloud (i.e. Couper 2003; Smith and Beckmann 2005; Lázaro Ibarrola 2011). Lázaro Ibarrola (2011) tested the efficacy of a reading aloud based on the imitation of original English recordings to improve the English pronunciation of university students. During a whole semester, students were provided with a wide range of recorded texts from films and TV series. After listening to those recordings, they had to imitate the pronunciation of the original recordings. In order to investigate whether there was an improvement in their pronunciation, two recordings of the same text were analysed. In addition, the author was also interested in examining whether students 
were able to transfer the improvements to their free speech and thus, a recording on free speech was also analysed. An individual questionnaire to gather students' own impressions about the usefulness of the reading aloud task was administered as well. Even though there was an improvement from the first recording to the second one, the students' pronunciation was only slightly better in the second recording and the speeches were more intelligible but did not seem to have more English-like suprasegmental features. Those improvements were not transferred to students' free speech, in particular suprasegmental features. This was explained by the fact that in free speech students had to talk about a topic of their own choice so the focus was solely on oral language, whereas in the case of reading, students were provided with the texts to imitate. Therefore, for certain speakers, their free speech was more intelligible despite sounding more Spanish. All in all, the results of the questionnaire indicated a firm satisfaction with the imitation practice. But despite the positive outcomes of the study, the author mentions certain methodological limitations such as the use of different extracts for reading aloud on the part of students. An extract selected by the teacher could solve the problem of students facing different levels of difficulty, a limitation we have taken into account in order to design the study presented below.

The studies by Smith and Beckmann (2005) or Couper (2003) have examined the use of noticing in reading aloud activities. Those studies have concluded that noticing facilitates improvement in pronunciation as well as in other areas such as writing. Smith and Beckmann (2005) undertook an action research project in order to test whether a noticing-reformulation assessment technique was useful for students. In a noticing phase, learners had to listen to and analyse their own speech according to specific phonetic features and then compare their pronunciation to that of a model pronunciation of the same text. In a reformulation phase, students had to work on improving the targeted aspects of their pronunciation and reformulate their text with the aim of bringing their pronunciation closer to the model. Subsequently, in a questionnaire administered after the pronunciation strand, learners self-reported that their pronunciation had improved. In another piece of action-research, Couper (2003) examined the effectiveness of a pronunciation syllabus aimed at post-intermediate university students that involved raising each individual learner's awareness of their difficulties with pronunciation and of the main features of spoken English. Results of pre- and post-test consisting of a reading aloud task and a speaking task revealed a clear improvement in accuracy of pronunciation on both tasks. Students were also surveyed to examine their reaction to the syllabus and their beliefs regarding the teaching and learning of pronunciation. The majority of the students favoured the systematic approach to the teaching of pronunciation taken in the programme. 
Even though the aforementioned studies have attested the efficacy of a reading aloud task to improve the pronunciation of learners, none of the studies have tested the efficacy of noticing together with awareness (Sharwood Smith 1993) in a reading aloud task. We are in the need of empirical replicable studies to inform pronunciation instruction and to attest the validity of these teaching techniques. The main aims of the present action-research study will be to test the efficacy of a reading aloud task with a noticing and awareness component addressed to university students and to gauge learners' beliefs regarding the use of this learning task for pronunciation.

\section{METHOD}

\subsection{PARTICIPANTS}

The participants in this action-research project were 20 first-year students from the University of the Basque Country who were attending a 6-credit course on Spoken English, a compulsory subject from the BA in English Studies. These students were receiving 70\% of their instruction in English, had an 'English Language' subject aimed at a B2 level according to the Common European Framework of Reference for Languages and some other subjects in their native language/s (Basque and/or Spanish). They had not had explicit instruction on pronunciation before. Table 1 shows the characteristics of the participants.

Table 1. Participants.

\begin{tabular}{|c|c|c|c|}
\hline Age & Gender & Year & Degree and Subject \\
\hline \multirow{2}{*}{$18-20$} & 6 male & \multirow{2}{*}{1 st } & English Studies \\
\cline { 2 - 2 } & 14 female & & Spoken English \\
\hline
\end{tabular}

\subsection{COURSE DESCRIPTION}

The course on spoken English started at the beginning of September and finished at the end of December. This course offered students theoretical and practical lessons consisting of a range of activities that gave them practice in pronunciation for both speaking and understanding as well as the opportunity to improve their listening comprehension and speaking skills at level B2. Classes were devoted to pronunciation training, reading aloud practice, dictation, listening comprehension and speaking practice. Classes were interactive and studentcentered. Activities were carried out both individually and in groups. All the sessions took place in one of the language labs at the Faculty of Arts. 
In the case of pronunciation training, the instructor followed an explicit and systematic approach. During the first weeks, students received initial lessons on key points in pronunciation: a description of the sounds of English according to place of articulation, manner of articulation and voice; the use of weak forms; stress; intonation patterns; and connected speech phenomena (the pronunciation of the -(e)s and -ed morphemes, syllabic consonants, linking of sounds, among others). At the same time, learners were trained on both perception and production of sounds through a series of activities devoted to particular sounds, as well as on prosodic features. We cannot forget that the advantages of using phonetic symbols in foreign language teaching are manifold: increased awareness of L2 sound features, 'visualisation' of such intangible entities as sounds, increased learner autonomy, among others, but also that any potential benefit depends on how notation is taught (Mompean 2005). At the time of selecting the most appropriate activities, the instructor tried to focus on areas of difficulty for Spanish/Basque learners of L2 English (see Gallardo del Puerto 2005).

Apart from these lessons and activities on pronunciation training, ten reading aloud written texts were selected by the teaching team in charge of the different groups that took this course. This specific task enables the learner to concentrate both on segments and suprasegments and to put into practice the knowledge gained through more guided activities. Learners were provided with 10 different texts to be recorded in the lab throughout the semester ${ }^{1}$. Learners recorded a text once a week during 10 weeks. Learners began to record the first text at the very end of September. Text 5 and text 10 were selected for assessment by the teaching team of this course and were assessed by instructors according to articulation of sounds, stress placement and intonation. These two reading aloud texts were worth $20 \%$ of the final mark of the course. Figure 1 illustrates the different steps followed for each recording. Noticing the gap, awareness and explicit feedback are key issues in the design of this reading aloud task. In the noticing phase, learners listened first of all to a model text uttered by the instructor of the course who had a solid training in phonetics and knowledge of those areas of phonetic difficulty for Spanish/Basque learners. Then students had to listen to their own recordings of the same text in order to compare their performance to the model text and to notice the gap. In the awareness phase the instructor showed a transcription of the text recorded, analyzed it together with the students (i.e. students were asked to look for those contexts of syllabic consonants, use of weak forms, among other things)

\footnotetext{
1 Note that unlike Lázaro Ibarrola (2011) learners did not have to perform an imitation task. As it was also stated above, note that in contrast to previous studies (Couper, 2003; Smith and Beckmann, 2005) the type of reading aloud task implemented in the course described did not only have a noticing but also an awareness component.
} 
and drew learners' attention to problematic aspects of the reading aloud text. They listened again to their own recordings at the same time they were looking at the transcription provided. The teacher randomly provided feedback with metalinguistic explanations to some of the students. Students then were able to reflect on their own problems regarding the articulation of sounds, stress and intonation and they noted down their errors to correct them for subsequent texts.

1. Initial lessons devoted to theoretical points.

2. Preparation of Text at home.

3. Recording in lab.

4. Model input: teacher's performance.

5. Noticing the gap. Listen to their speech. Comparison of own production with model.

6. Awareness phase. Analysis of model transcription: weak forms, syllabicity, linking $r$, -ed and -es endings, stress and intonation.

5. Listen to own speech following a transcription.

6. Teacher provides feedback at random.

7. They note down their errors to correct them for subsequent texts.

Figure 1. Summary of noticing-awareness technique in a reading aloud task.

\subsection{INSTRUMENTS}

Data were gathered by two different instruments: a reading aloud task and a written questionnaire. The author of the present paper and instructor of one of the groups wanted to investigate whether an improvement could be observed from the first reading aloud assessment task to the second one and in turn to evaluate the efficiency of this particular task for the teaching of pronunciation. As claimed by Derwing and Munro (2005), teachers cannot rely on their own intuition and their decisions as regards the election of activities should be grounded in research. Additionally, as in the case of other studies (i.e. Couper 2003, Smith and Beckmann 2005; Lázaro Ibarrola 2011), a questionnaire was designed in order to measure students' perception of improvement of their pronunciation through a reading aloud task and to elicit data about their beliefs regarding the use of this learning task.

Students were first tested on articulation of sounds, stress placement and intonation through two different reading aloud texts of 200 words at two different points in time. Learners recorded the first assessment text at the end of October and 
the second during mid December. As stated in the syllabus of the course, learners had to show that (1) they articulated the sounds of English accurately, (2) they stressed the words precisely, and (3) they read the texts with appropriate intonation. Learners were holistically ${ }^{2}$ assessed on three categories according to the agreement reached by the teaching team in charge of the different groups that took the course: articulation of consonants and vowels and other phonetic features such as the use of syllabic consonants, weak forms, pronunciation of -ed and -(e)s ( 5 points); stress placement ( 4 points) and intonation (1 point). Each of these aspects was rated individually. An overall score was also calculated adding the three criteria. The maximum points score was 10 points.

In order to complement the evaluation of the two reading aloud texts, a questionnaire was administered to the students at the end of the course and prior to the publication of the marks for the second text. The instructor was interested in measuring students' perception of improvement of their pronunciation through a reading aloud task and to elicit data about their beliefs regarding the use of this learning task. This questionnaire contained thirty-six 5point Likert scale items in which students had to show their degree of agreement with a given statement. It was divided into 5 sections. The first section contained 12 items devoted to teaching methods and strategies used by the instructor in the course. The second section included 5 items related to student learning affect. The third section was made up of 13 items regarding evaluation of course materials. The fourth section consisted of 2 items devoted to a general summative evaluation of the course and the last section gave learners the possibility of describing some good points about the course and areas of improvement. For space constraints, only 3 items of the questionnaire will be analyzed which bear directly with the reading aloud task: item 19. The feedback I have received on my reading aloud has enhanced my learning; item 24. The reading aloud practice has helped me improve my pronunciation, stress and intonation in connected speech; and item 25. In terms of reading aloud, I have experienced a clear improvement from Text 5 to Text 10.

\footnotetext{
2 A holistic assessment is common practice in the case of studies dealing with different aspects of spoken production (Cenoz 1991; Gallardo del Puerto, Gómez Lacabex and García Lecumberri 2009; Gallardo del Puerto and Gómez Lacabex 2013). In the present paper, students were assessed by the instructor of the course, a non-native speaker of English with linguistic training. Judgments of speech performed by non-native judges who are teachers of English and who are familiar with the students' L1s have been found to be similar to the ones from native-speakers (Gallardo del Puerto, García Lecumberri and Gómez Lacabex, in press).
} 


\section{RESULTS}

\subsection{READING ALOUD TEXTS}

Table 2 presents the results obtained by the learners on the two recorded reading aloud texts (mean and standard deviation (SD)):

Table 2. Reading aloud results

\begin{tabular}{|c|c|c|c|}
\hline & Text number & Mean & SD \\
\hline \multirow{2}{*}{$\begin{array}{c}\text { Articulation } \\
(\mathbf{m a x}=5)\end{array}$} & $\mathbf{5}$ & 3.53 & 1.08 \\
\cline { 2 - 4 } & $\mathbf{1 0}$ & 4.16 & 0.86 \\
\hline $\begin{array}{c}\text { Stress } \\
(\mathbf{m a x}=\mathbf{4})\end{array}$ & $\mathbf{5}$ & 2.68 & 0.85 \\
\cline { 2 - 4 } & $\mathbf{1 0}$ & 3.05 & 0.86 \\
\hline $\begin{array}{c}\text { Intonation } \\
(\text { max=1) }\end{array}$ & $\mathbf{5}$ & 0.40 & 0.26 \\
\cline { 2 - 4 } $\begin{array}{c}\text { Overall score } \\
(\mathbf{m a x}=\mathbf{1 0})\end{array}$ & $\mathbf{1 0}$ & 0.53 & 0.18 \\
\cline { 2 - 4 } & $\mathbf{5}$ & 6.61 & 1.99 \\
\hline
\end{tabular}

In order to examine whether an improvement could be observed from Text 5 to Text 10, two types of analyses were conducted. In the case of the variables 'articulation', 'stress' and 'overall score' for both texts analyzed, the data met the criteria for normal distribution and consequently, a T-test analysis was computed so as to establish comparisons between the means of the variables for Text 5 and Text 10. However, the data obtained in 'intonation' for Text 10 did not meet the criteria of normal distribution, and consequently, we used the non-parametric test Wilcoxonrank in order to compare the means for 'intonation' obtained in the two texts recorded.

As can be observed in Table 2, learners obtained better means in the case of Text 10 in all the variables analysed. Learners significantly improve their articulation of sounds from Text 5 to Text $10(\mathrm{t}=-4.730, \mathrm{p}=.000)$, stress placement $(\mathrm{t}=-3.822, \mathrm{p}=.001)$ and intonation $(\mathrm{z}=-2.671, \mathrm{p}=.008)$. When overall scores were compared, statistically significant differences were observed as well ( $\mathrm{t}=-5.891, \mathrm{p}=.000)$.

\subsection{QUESTIONNAIRE}

Table 3 presents the results of the responses to the three items that were directly related to the reading aloud task. Mean scores and standard deviations 
were calculated for each item. Note that 5 indicates 'totally agree' and 1 'totally disagree'.

Table 3. Questionnaire results.

\begin{tabular}{|l|c|c|}
\hline & Mean & SD \\
\hline $\begin{array}{l}\text { Item 1. 'The reading aloud practice has helped me improve } \\
\text { my pronunciation, stress and intonation in connected } \\
\text { speech' }\end{array}$ & 4.38 & 0.72 \\
\hline $\begin{array}{l}\text { Item 2. 'In terms of reading aloud, I have experienced a } \\
\text { clear improvement from text 5 to text 10' }\end{array}$ & 4.06 & 0.68 \\
\hline $\begin{array}{l}\text { Item 3. 'The feedback I have received on my reading aloud } \\
\text { has enhanced my learning' }\end{array}$ & 4.00 & 0.97 \\
\hline
\end{tabular}

As can be observed, the means for the three items were quite high. In the case of the first item with a score of 4.38 , it is implied that learners feel that the reading aloud practice done in class has helped them improve their pronunciation, stress and intonation in connected speech. Similarly, a mean of 4.06 in the second item suggests that students feel they have improved from Text 5 to Text 10. As for the feedback received on their reading aloud, the average rate registered for this item (4) leads us to think that the feedback they received on their reading aloud did enhance their learning.

If we look at Figure 2, we can observe the distribution of responses for each item. In the case of item 1 the vast majority of students agreed on the effectiveness of the reading aloud task to improve their pronunciation, intonation and stress in connected speech. To be more precise, $50 \%$ of students totally agreed with the statement and $37.5 \%$ just agreed. In the case of item 2 , an ample majority of students had positive beliefs regarding this statement: $56.3 \%$ of the students answered 'Agree' and $25.0 \%$ 'Totally agree' that they had experienced a clear improvement from Text 5 to Text 10. When answering item 3, we can observe more moderate responses: $37.5 \%$ of the students totally agreed, 31.3 agreed, while $25 \%$ neither agreed nor disagreed and 6.3\% disagreed that the feedback they had received on their reading aloud had enhanced their learning.

All in all, after examining the data gathered through this questionnaire, these data seem to indicate that in general, students consider the reading aloud task a good instrument to improve their pronunciation in English. 


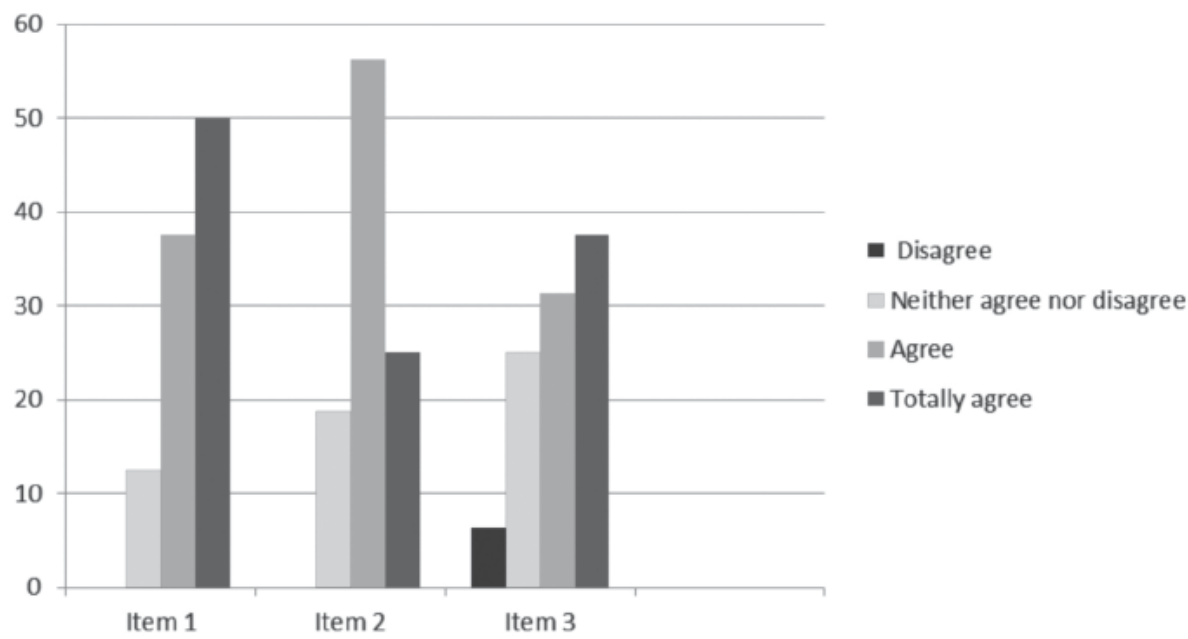

Figure 2. \% of subjects and responses.

\section{DISCUSSION AND CONCLUSION}

One of the aims of the present study was to test the efficacy of a reading aloud task with a noticing and awareness component addressed to university students. The assessment of the two recorded reading aloud tasks revealed that learners improved in all the categories: articulation, stress and intonation. Explicit instruction seems to be effective in pronunciation in line with other studies that have attested the efficacy of explicit instruction on oral production (de Bot 1983; Leather 1990; Couper 2003; Derwing and Munro 2005; Smith and Beckman 2005, among others). Previous research has already shown that noticing facilitates improvement in pronunciation (Couper 2003; Derwing and Munro 2005; Smith and Beckmann 2005). The assessment of the reading aloud task has revealed that noticing together with metalinguistic awareness and feedback are also effective in the teaching of pronunciation, at least to adult learners.

The second aim of the study was to gauge learners' beliefs regarding the use of this reading aloud task for the learning of pronunciation. The analysis of the questionnaire has shown that learners firmly believe that reading aloud practice has helped them improve their pronunciation. These results go in line with other investigations that have surveyed students on the efficacy of explicit instruction in the case of pronunciation (Couper 2003; Smith and Beckmann 2005). Most participants also think their pronunciation has improved from their first assessment 
to the second one. These results mirror teacher's assessment of the reading aloud task, as it is not only the case that participants in the present study have been observed to improve articulation, stress and intonation, but that they also value the reading aloud task for the learning of pronunciation. This seems to imply that students were aware of their initial problems with pronunciation. We cannot forget that this task includes a noticing and awareness component that enables them to notice the differences between their own production and that of more proficient speakers in the first place, and subsequently, to really understand the problems they may have with certain sounds, stress placement or patterns of intonation. Taking into account both the assessment of the reading aloud task and the learners' favorable opinions regarding the use of this learning task in class, perception and imitation as widespread practices in the teaching of pronunciation - should be accompanied by awareness. Imitation alone might not be enough in the case of adults who are in the need of metalinguistic information that will enable them to understand the types of errors committed and to find ways to improve for subsequent texts. Students also believe in the importance of feedback on their reading aloud practice. We cannot forget that form-focused instruction includes not only noticing and awareness tasks but also corrective feedback which prevents fossilized phonological performance (Pennington 1997). Empirical studies carried out in classroom and laboratory contexts have shown that oral corrective feedback facilitates L2 acquisition (Doughty and Varela 1998; Ayoun 2001; Leeman 2003; McDonough 2005; Mackey 2006), as it can lead to notice errors produced and to formulate hypotheses about the target language forms (Gass and Mackey 2007). Therefore, it is not only the case that learners consider feedback an important aspect in the teaching of pronunciation but that research has attested its effectiveness in the acquisition of a L2.

Different types of feedback exist from more explicit to less explicit. Even though implicit feedback such as negotiation and recasts are widely used by teachers, in the pronunciation class with adults it is common practice to add metalinguistic explanations as well. In fact, results from various investigations that have compared different feedback types (recasts, negotiation, prompts or metalinguistic explanations) suggest that when two or more implementations of negative feedback are compared, the more explicit one leads to larger gains (Carroll, Roberge and Swain 1992; Norris and Ortega 2000). The present study seems to support the inclusion of explicit corrective feedback in the pronunciation class addressed to university learners.

In conclusion, the findings reported in this action-research paper confirm the effectiveness of a noticing and awareness component in a reading aloud task, and in turn, the value of explicit instruction in the teaching of pronunciation. Furthermore, courses such as the one depicted in this paper that incorporate 
phonological instruction together with opportunities for perception and production at the segmental and suprasegmental level may lead to a greater improvement on the part of the student than courses devoted primarily to the description and transcription of sounds. The opinions gathered through the questionnaire administered to the participants in the present study seem to support the integration of both theoretical issues regarding the English sound system and activities that make students aware of their problems with pronunciation and help them improve the articulation of segments and the suprasegmental features. However, some limitations of the study should be noted so as to take them into account for future studies. Students' recordings of Text 5 and 10 were the only ones assessed for the present study. For forthcoming research, an evaluation of the 10 texts recorded in class should be carried out so as to get a better picture of the development of the students. Additionally, external raters should be employed for the analysis of the different recordings. Finally, as the instructor of the course was a non-native speaker of English, a follow-up of the present study could examine whether having a native teacher makes a difference.

\section{ACKNOWLEDGEMENTS}

The author is grateful for grants awarded by the Spanish Ministry of Economy and Competitiveness (FFI2012-32212), the University of the Basque Country (UFI 11/06) and the Basque Government (IT311-10). The author also wants to acknowledge the feedback provided by her colleague Dr. Francisco Gallardo del Puerto on an earlier version of the paper.

\section{REFERENCES}

Atay, C. 2007. "Teacher research for professional development". ELT Journal 62 (2): $139-147$.

Ayoun, D. 2001. "The role of negative and positive feedback in the second language acquisition of the passé compose and the imparfait". The Modern Language Journal 85 (2): 226-243.

Barrera Pardo, D. 2004. "Can Pronunciation Be Taught? A Review of Research and Implications for Teaching”. Revista Alicantina de Estudios Ingleses 17: 6-38.

Benson, E. D. and M. P. García Mayo. 2008. "Awareness of orthographic form and morphophonemic learning in EFL". Languages and Cultures in Contrast Band Comparison. Ed. M. A. Gómez González, J. L. Mackenzie, and E. M. González Álvarez. Amsterdam and Philadelphia: John Benjamins. 299-326. 
Carroll, S., Roberge, Y. and M. Swain. 1992. "The role of feedback in second language acquisition: Error correction and morphological generalization". Applied Psycholinguistics 13: 173-198.

Cenoz, J. 1991. Enseñanza del Inglés como L2 o L3. Leioa: Universidad del País Vasco.

Cenoz, J. and M. L. García Lecumberri. 1999. "The effect of training on the discrimination of English vowels". International Review of Applied Linguistics 37: 261-275.

Couper, G. 2003. "The value of an explicit pronunciation syllabus in ESOL teaching". Prospect 18: 53-70.

de Bot, K. 1983. "Visual feedback of intonation 1: Effectiveness and induced practice behavior". Language and Speech 26: 331-350.

Derwing, T. and J. Munro. 2005. "Second Language Accent and Pronunciation Teaching: A Research-Based Approach”. TESOL Quarterly 39 (3): 379-397.

Doughty, C. and E. Varela. 1998. "Communicative focus on form". Focus on form in classroom second language acquisition. Eds. C. Doughty and J. Williams. New York: Cambridge University Press. 114-138.

Francis, S., Hirsch, S., and E. Rowland. 1994. "Improving school culture through study groups". Journal of Staff Development 13: 12-15.

Gallardo del Puerto, F. 2005. La adquisición de la pronunciación del inglés como tercera lengua. Leioa: University of the Basque Country.

Gallardo del Puerto, F. and E. Gómez Lacabex. 2008. "La enseñanza de las vocales inglesas a los hablantes de español". Pulso 31: 37-66.

Gallardo del Puerto, F. and E. Gómez Lacabex. 2013. "The impact of additional CLIL exposure on oral English production". Journal of English Studies 11: 113-131.

Gallardo del Puerto, F., Gómez Lacabex, E. and M. L. García Lecumberri. 2009. "Testing the effectiveness of content and language integrated learning in foreign language contexts: The assessment of English pronunciation". Content and language integrated learning: Evidence from research in Europe. Eds. Y. Ruiz de Zarobe and R. M. Jiménez Catalán. Clevedon, UK: Multilingual Matters. 63-80.

Gallardo del Puerto, F., García Lecumberri, M. L. and E. Gómez Lacabex. In press. "The assessment of foreign accent and its communicative effects by naive native judges vs. experienced non-native judges". International Journal of Applied Linguistics.

García Lecumberri, M. L. 2001. "Phonetic awareness". Language Awareness in the Foreign Language Classroom. Eds. D. Lasagabaster and J. Sierra. Bilbao: Universidad del País Vasco. 237-251. 
Gass, S. M. and A. Mackey. 2007. "Input, interaction, and output in second language acquisition". Theories in second language acquisition: An introduction. Eds. B. Van Patten and J. Williams. Mahwah, NJ: Lawrence Erlbaum. 175-199.

Goldsworthy, C. L. 1998. Sourcebook of Phonological Awareness. San Diego: Singular Publishing Group.

Gómez Lacabex, E. and F. Gallardo del Puerto. 2014. "Raising perceptual phonemic awareness in the EFL classroom". Concordia Working Papers in Applied Linguistics 5: 203-215.

Jamieson, D. G. and D. E. Morosan. 1986. "Training non-native speech contrasts in adults: Acquisition of the English/Theta/-/d/ contrast by francophones". Perception and Psychophysics 40: 205-215.

Jenkins, J. 2000. The Phonology of English as an International Language. Oxford: OUP.

Jones, H. R. 1997. "Beyond 'listen and repeat': pronunciation teaching materials and theories of second language acquisition”. System 25 (1): 103-112.

Kenworthy, J. 1989. Teaching English Pronunciation. New York, Longman.

Krashen, S. 1982. Principles and practice in second language learning and acquisition. Oxford: Pergamon.

Lázaro Ibarrola, A. 2011. "Imitating English oral texts: A useful tool to learn English Pronunciation?”. Porta Linguarum 16: 49-63.

Leather, J. 1990. "Perceptual and productive learning of Chinese lexical tone by Dutch and English speakers". Proceedings of the 1990 Amsterdam Symposium on the Acquisition of Second-Language Speech. Eds. J. Leather and A. James. Amsterdam: University of Amsterdam. 72-97.

Leeman, J. 2003. "Recasts and second language development: Beyond negative evidence". Studies in Second Language Acquisition 25 (1): 37-63.

Lightbown, P. and N. Spada. 2013. How languages are learned. Oxford: Oxford University Press.

Lyster, R. 2007. Learning and teaching languages through content: A counterbalanced approach. Amsterdam: John Benjamins.

Mackey, A. 2006. "Feedback, noticing and instructed second language learning". Applied Linguistics 27 (3): 405-430.

Martínez Adrián, M., Gallardo del Puerto, F., and J. Gutiérrez Mangado. 2013. "Phonetic and syntactic transfer effects in the English interlanguage of BasqueSpanish bilinguals". Vigo International Journal of Applied Linguistics 10: 51-83. 
McDonough, K. 2005. "Identifying the impact of negative feedback and learners' responses on ESL question development". Studies in Second Language Acquisition 27: 79-103.

Mompean, J. A. 2005. "Taking advantage of phonetic symbols in the foreign language classroom". PTLC2005. <http://www.academia.edu/4670077/Taking_Advantage_ of_Phonetic_Symbols_in_the_Foreign_Language_Classroom $>$.

Norris, J. M. and L. Ortega. 2000. "Effectiveness of L2 instruction: A research synthesis and quantitative metanalysis". Language Learning 50 (3): 417-528.

Pennington, M. C. 1997. "Phonology in language teaching: Essentials of theory and practice". Beyond Method: Components of second language teacher education. Eds. K. Bardovi-Harlig and B. Hartford. Boston: McGraw-Hill. 67-87.

Schmidt, R. W. 1990. "The role of consciousness in second language acquisition". Applied Linguistics 11: 129-158.

Setter, J. and J. Jenkins. 2005. "Pronunciation”. Language Teaching 38: 1-17.

Sharwood Smith, M. 1981. "Consciousness-raising and the second language learner". Applied Linguistics 2: 159-169.

Sharwood Smith, M. 1993. "Input enhancement in instructed SLA: Theoretical bases". Studies in Second Language Acquisition 15: 165-179.

Smith, J. and B. Beckmann. 2005. "Improving pronunciation through noticingreformulation tasks". PTLC: 1-4.

Spada, N. 1997. "Form-focused instruction and second language acquisition: A review of classroom and laboratory research". Language Teaching 30: 73-87.

Strange, W. and S. Dittman. 1984. "Effects of discrimination training on the perception of / rl/ by Japanese adults learning English". Perception and Psychophysics 36: $131-45$. 